\title{
Vital Publics of Pure Blood
}

\section{THOMAS STRONG}

\begin{abstract}
Blood supplies have become indexes of national security and the public good. While blood shortages can provoke anxiety, controversies continue to erupt in many countries over proper donor screening, especially with reference to HIV. This article sketches these dynamics in several global settings, focusing especially on activist efforts by gay men to reform exclusionary blood donor guidelines. The contours of the debate recall familiar conflicts between the putative demands of public health and the rights of individuals in the era of AIDS. However, if gay activists marshal a discourse of individual rights vis-a-vis forms of institutional exclusion, they also seek a broader shift in social and cultural understandings of gay identity. To capture this complex interplay of citizenship and sociality, risk and responsibility, the article introduces the notion of 'vital publics' to refer to the peculiar associational form represented by blood supplies. Vital publics are kinds of embodied association elicited through the generalized exchange of body - in this case, blood. Hailed to 'give life' by the jargon of the pervasive social marketing of varied blood service systems, activists seek to contribute to the life of the 'vital public' that transfusion medicine calls into being.
\end{abstract}

Keywords blood, public, risk, sexuality

Most countries currently ban sexually active gay men from donating blood. The policy is intended to reduce the risk of transfusion-transmitted HIV infections. Men who have sex with men - 'MSM' in the parlance of much medical discourse on HIV (cf. Young and Meyer, 2005) - are thought to be at higher risk of infection and therefore a potential danger to the safety of the blood supply. Though all donated blood is tested for known pathogens, assays intended to detect HIV in donated blood are not 100 percent foolproof, in part due to the notorious but ever-shrinking 'window period' between the onset of HIV infection in an

Body E Society Copyright (C) The Author(s) 2009, Reprints and permissions:

http://www.sagepub.co.uk/journalspermissions.nav

Vol. 15(2): 169-191; DOI: 10.1177/1357034X09103441 
individual and the ability of tests to detect the virus in his or her blood. To 'close this window' (Busch, 2001), pre-donation assessments, usually questionnaires completed by potential donors or interviews conducted by phlebotomists or other staff, exclude 'high-risk individuals' from the donor pool - those individuals who have engaged in behaviors thought to put them at risk for HIV infection. These surveillance measures may be called 'behavior risk-factor screening' or 'donor self-exclusion'. HIV is not the only target; other diseases of concern include hepatitis, malaria, West Nile Virus and CJD. Behaviors or markers which exclude persons from the donor pool vary from country to country, as do the ways in which exclusions are phrased, due in part to specific epidemiological circumstances. Nevertheless, in the US, Canada, the UK and in many other countries, a man who has had sex with another man even once since 1977 is not allowed to give blood, and HIV remains the most commented upon and the most feared potential contaminant to blood supplies everywhere. From 1983, when transfusion-transmitted HIV was conclusively agreed to pose a major threat to the safety of the blood supply (Busch, 2006: 1626; Starr, 1999: 266-98), until relatively recently, sexually active gay men have been uniformly excluded as potential donors, a ban affirmed in numerous and diverse national regulations and international consensus statements (see Hochberg, 2001: 231 n. 2).

This fact is changing. Presently, Portugal, Spain, South Africa, Russia, Italy and Thailand allow men who have had sex with men to donate blood. Most of the countries that have rescinded bans on gay men giving blood have shifted the screening protocol away from questions that appear to assess sexual identity per se toward questions more squarely focused on sexual practices as such. Instead of assessing whether a male potential donor has ever had sex with another man, these measures seek to assess the kind of sex an individual has engaged in, excluding individuals who have engaged in 'high-risk' sex and moving assessment of potential risk from person to practice, so to speak. Most recently, Agence France-Presse reported in April 2008 that Thailand's Red Cross would revise its policy, stating that excluding gay men was discriminatory. Quoting Soisaang Pikulsod, director of the Thai Red Cross National Blood Center, the article says: 'The Red Cross will rework the form to include more questions about all types of sexual behavior, gay or heterosexual, that could increase the risk of diseases such as AIDS' (Agence France-Presse, 2008). In Australia, the ban on gay men is currently narrowed only to those who have been sexually active in the preceding 12 months, a less restrictive ban than those found in countries such as the US or the UK, though this policy is also opposed by Australian activists who claim it is discriminatory. Michael Cain, a Tasmanian man, has lodged a pending complaint with the Tasmanian Anti-Discrimination Tribunal. ${ }^{1}$ Across the globe, 
contemporary activist arguments for inclusion have been bolstered by new technologies that enable more precise HIV testing and by new studies showing that the risks involved in allowing sexually active gay men to donate blood are so small as to be almost unimaginable (Busch, 2006). Studies that attempt to specify risk are translated into public messages emphasizing that transfusion-related risk of HIV infection is so small that it can no longer be 'directly measured' but must rather be modeled mathematically. These studies have convinced many, including the leadership of major blood donor organizations in the US and elsewhere (such as the Red Cross, the American Association of Blood Banks and so on), that the ban on gay blood donors is no longer necessary.

Gay activists and allies in many international settings are pushing for removal of blanket bans on MSM giving blood. Indeed, together these efforts comprise nothing less than a global movement, taking shape in the arenas of public opinion and official adjudication. They are but one instance of a series of linked gay and lesbian efforts to remove barriers to full participation in public life. Often finding inspiration, and authorization, through cross-national linkages (cf. Tsing, 2007: 39-42; see also Tsing, 2000: 350-1), blood donation activists pursue diverse strategies to press their claims. These include formal litigation in courts of law or civil rights commissions (in Australia and the Netherlands), direct action (in Hong Kong), or petitions to government bodies such as houses of parliament (in Scotland). In the US, at institutions with non-discrimination policies, activists have sometimes successfully pressured decision makers into refusing blood drives. And in social fora of all kinds - campus debates, cable news programs, online bulletin boards, even Facebook and YouTube - individuals subject to exclusion for reasons that they feel are unfair state their case and seek reform, trying to build support through mediated politics. If their agendas and audiences reflect differences in the institutional organization of transfusion medicine in varied national contexts (as between blood systems organized by national states and those organized principally by non-governmental organizations), their messages and tactics cluster around a recurrent set of themes. They say that systematically excluding gay men from donating blood is a form of 'discrimination' that impinges upon the 'right to give life', often framing the issue in the familiar terms of contemporary multicultural identity politics in liberal democracies (cf. Hochberg, 2001).

The contours of this debate recall familiar conflicts between the putative demands of public health and the rights of individuals in the era of AIDS, especially given the liberal political arenas in which these discussions often unfold (Povinelli, 2006: 27-94; Scheper-Hughes, 1993). However, if these activists marshal a discourse of individual rights vis-à-vis forms of institutional exclusion, 
they also seek a broader shift in social and cultural understandings of gay identity; they insist that their exclusion from donation reinscribes a persistent equation of gay identity with disease and pathology. They wish to push gay identity out from under the sign of 'AIDS', a contemporary scarlet letter seen to scar a new, normal public face for gay men (Sullivan, 1996; cf. Warner, 1999). Moreover, in creating concerned publics through their efforts, they seek reflexively to reform the very meaning of 'public', a term that has haunted discussions of HIV/AIDS ever since the earliest representations of the disease quarantined the 'general public' from it (Crimp, 1988; Kramer, 1989; Patton, 1990).

\section{Vital Publics}

These efforts reveal ways in which publics today are more and more tightly linked to the circulation not only of semiotic media (Warner, 2005), but also to the circulation of bodily substance. Discourse about this circulation comprises an emergent form of politics concerned about and defined as 'life itself' (Biehl, 2007; Rose, 2006; cf. Comaroff, 2007). We know that reflexive biological knowledge, especially of the molecular variety (Rose, 2006: 11-15), is transforming selves and social relations, a process cleverly captured in Rabinow's neologism 'biosociality' (Rabinow, 1992; see also Hacking, 2006a). We know further that as health, including public health, has become a principal focus of government (and the market), meanings of citizenship have mutated to include the 'biological' alongside the political (Masco, 2006: 324-8; Rose, 2006: 131-55). Yet blood donation and transfusion medicine, now nearly a century old, invite contemplation of relations created not only through reflexive knowledge about the body and the identities that knowledge creates, but also through the exchange of body itself. How to understand this 'circulation' is now a rather old concern across the human and medical sciences (Fox and Swazey, 1978; Parsons et al., 1972; Strathern, 1992; Titmuss, 1971; Waldby and Mitchell, 2006). Start with a name. What will we call this associational form, itself inaugurated through the call to donate? What are the social relations that together comprise transfusion medicine? Neither 'biosociality', which names groups that form around emergent biomolecular phenomena, nor 'bioidentity' (Waldby et al., 2004), nor even 'biological citizenship' (Petryna, 2002), I think quite capture the communal spirit blood supplies are held to represent by virtue of the unique forms of circulation from which they emerge.

To better grasp the way that blood supplies yield a public good from a particular transactional form (altruistic donation), I suggest the term 'vital publics': sets of stranger relationships defined by those who may give, receive or otherwise 
benefit from, blood and other biological material, the putative substances of 'life'.2 Vital publics are forms of embodied association elicited through the generalized exchange of body - in this case, blood. By analytic analogy with the 'autopoietic' mediated publics theorized by Warner (2005; cf. Arnoldi, 2006), key qualities of vital publics can be made visible. They draw persons into reciprocal relations peculiarly characterized by an intimate strangerhood. Altruistic donations by anonymous others, gifts 'addressed' in a sense to both no one and everyone, elicit further donations through the feeling of generalized obligation they produce. Blood supplies therefore recursively index these publics: the product of the conceptually (or perhaps literally) congealed donations of persons, they in turn interpellate potential donors and recipients as their subjects through the health security they represent, promise and in fact often deliver. Importantly, contemporary blood systems, as vital publics, often literalize the conventional symbolism of blood and nation, binding social reproduction tightly into relations of 'consanguinity'. Participation in the vital public might therefore be seen as a unique duty associated with the biological citizen, even though, as Valentine observes: 'Blood donation ... remains a public practice at the same time that certain kinds of public are precluded from it' (2005: 116). Moreover, these vital publics are one among many 'vital systems' that receive the increasingly intense scrutiny of the security apparatuses of states (Collier et al., 2004; Lakoff, 2007). Indeed, the tight historical and contemporary linkages between transfusion medicine and varieties of violence (Copeman, 2008; Starr, 1999) reveal just how important transfusion medicine has been to the constitution of the major political units (i.e. nation-states) of the contemporary era (see e.g. Waldby and Mitchell, 2006: 1-6; see also Churchill and Kurtz, 1988; Rabinow, 1999: 78-80).

Vital publics represent and elicit a form of cultural intimacy that exceeds the reach of affective or symbolic identification (Herzfeld, 2004; see also Herzfeld, 1992), in part because they bind people into relations in which the intimate acts of others always already impinge upon them. Blood supplies bring sex and society into touch, crossing gingerly between private and public. I suggest that the intense focus that blood/HIV scandals continue to receive devolves specifically from this very juncture and from the awareness that it generates: much as we may wish to shield ourselves from the others in our midst, we are ever more intimately bound to them nonetheless (Povinelli, 2006: 175-236). This observation yields a question: Can 'vital publics' embrace the sexual minorities they have long excluded?

If this relational arena is characterized by fretful and panic-inducing points of contact between public and private, between the intimate and the political, then the reasons for the great importance attached to it by the activists clamoring to be let in can start to be understood. In this article, I sample some of these efforts 
and ask what they can tell us about the meaning of blood (transfusion) in modern society. ${ }^{3}$ Most studies of blood donors focus on motivation (e.g. Dalsgaard, 2007; Healy, 2000; Royse and Doochin, 1995; Waldby et al., 2004), and are based on the discourse of those who qualify to donate. These have yielded manifold accounts of reciprocity (tyrannical or otherwise) and relationality (fictive or embodied) in the context of medical technologies. They explore meanings of nationality, personal responsibility, altruism and religion, often contributing to the perennial discussion about free markets and ethical obligations, or gifts and commodities (Strong, 1997). Ever since Titmuss's seminal and enormously consequential study The Gift Relationship was published (1971, 1997), analyses of blood donation and transfusion have also bridged arguments about market morality and public safety or health, especially in the wake of a series of (trans)national political crises that emerged in the 1980s and 1990s in relation to HIV and AIDS (see especially Feldman and Bayer, 1999). These studies spot danger when donor motivations are reduced to 'economic interest', as when people sell blood and body, sounding a lone note of caution against prevailing neoliberal winds.

This article examines these themes by considering those who stand outside the closed door to the blood mobile. I suggest that contemporary meanings of blood and its donation are starkly revealed through the dividing practices that structure participation and that stimulate the activism that is reforming blood policies across the globe. I sample three political strategies: a Hong Kong example, where activists pursued direct action and public shaming of Red Cross officials; a US campus model based on principles of open debate and donor sponsorship or substitution; and a UK effort to petition Parliament directly. The transnational reach of these efforts requires a moment of reflection. Though always rooted in the struggles and concerns of local communities at different levels of abstraction (city, region, nation), these actions disclose ongoing and emergent mutations in the meaning of 'human' today (Strong, 2002: 405). In so doing, they expose ways that the marshaling and management of blood supplies reflect and refract contemporary categories of personhood (Hacking, 2006b). One has only to remember that the category 'gay', and its cross-cultural social scientific cousin 'MSM', are quite new types of person in many global settings (see e.g. Boellstorff, 2005). Thus, if the meanings of blood donation are contested by gay men in many locales, gay men are also (re)defined by the practices of blood procurement. Blood, then, is a biosymbolic medium for the contemporary creation of persons and populations - and the publics through which they are joined - worldwide. Awareness of this fact provokes the intense hue and cry of controversy whenever the 'gift of life' exposes the risks that social relations must always bear. 


\section{7: Three Stories, Global Public?}

In September 2007, BBC News reported that 'Peru Blood Banks Face HIV Crisis' (BBC News, 2007). Following the revelation that at least four people had earlier in the year been infected with HIV through transfusions they received in a hospital in the port city of Callao, the Peruvian government took steps to close 240 blood banks in the country pending review of their screening protocol. In the BBC report, Jose Cruz of the Pan-American Health Organization (PAHO), a division of the World Health Organization (WHO), called the Peruvian situation 'worrying', and further claimed that as much as a quarter of Peru's blood supply was not properly screened according to the organization's standards (see also Cruz and Pérez-Rosales, 2003). Simultaneously, the government reported that 30 dialysis patients had been recently infected with hepatitis C. Yet the public face of the scandal, and the catalyst for its international attention, was Judith Rivera, shown in the BBC report facing a phalanx of news cameras as she tearfully testified to her ordeal. Over a montage of images of hospital corridors, plastic blood bags and tubes, and of Judith Rivera herself, the BBC journalist narrated:

The message for those who have had blood transfusions or who are awaiting them is: Don't panic. Contaminated blood was apparently donated by people unaware that they were carrying the virus but who managed to pass through nine stages of internationally approved checks. But that's come a little too late for Judith Rivera, after she was infected during surgery on her uterus with the virus that can lead to AIDS. [Voice of translator quoting Rivera] 'My uterus had to be removed because I had a tumor. When I went to pick up the HIV test, I was given the bad news that I had the virus. At that moment, my reaction was to end my life, because I couldn't deal with it.' At least four people, including an eleven month old baby have so far been infected. [Voice of translator, quoting Carlos Vallejo, Peruvian Health Minister] 'What we don't want people to do is panic. What we have to do is be more careful, strengthen our care to patients. We have been careful, but we have to be even more so.' Health officials say that around 40 blood banks have been closed because they did not meet basic standards. And testing was being carried out at 200 other blood banks. For Judith, and for her husband and four children, they must now face a long legal battle for compensation. And with the infected blood inside her, the uncertainty that will bring.

The case of Judith Rivera in 2007 follows an earlier outcry in 2004, when it was revealed that eight patients had been infected with HIV at a hospital in Lima, Peru (Fraser, 2005). All of those infections were linked to a single blood donor in a subsequent government investigation. The earlier scandal focused attention on pre-donation screening questions when it was discovered that hospital staff had used an outdated questionnaire and that they generally lacked proper training in such measures. Nevertheless, it was also true that news of the 2004 infections surfaced after the completion of a multi-year PAHO-sponsored Latin American blood safety initiative funded by the Bill and Melinda Gates Foundation. 
The recent Peruvian examples are but the latest in a series of AIDS-related scandals that have come to define transfusion medicine in the last 20 years (Cullinane, 2005; Erwin, 2006; Feldman and Bayer, 1999; Shao, 2006; Starr, 1999: 299-356). The scandals have exposed manifold weaknesses in the safety of blood systems, including those based principally on the 'safe' model of altruistic blood donation. In several European nations, in North America, in Japan and elsewhere, knowledge that thousands of transfusion recipients (and in the case of China, donors; see Shao, 2006) - and especially hemophiliacs who received industrial blood products pooled from dozens of separate donors - had been infected with HIV caused crises of confidence in government at all levels, and prompted calls for stricter surveillance of blood supplies. Blame and recrimination circulated within nations and between them, and a politics of purity and prophylaxis contributed to emergent definitions of 'innocence' and 'guilt' in the context of the ongoing epidemic in which tens of thousands were dying. The mass mediated image of the 'innocent' hemophiliac was a foil for the threatening and guilty 'homosexual' or 'IV-drug user' (Treichler, 1988).

In fact, early steps to exclude gay men from donating were met with resistance by both blood bank administrators and gay activists, though subsequent studies have shown that exclusion of gay donors substantially reduced risk of transfusion-transmitted HIV infections in the early years of the epidemic (Bayer, 1999; Busch 2006; Starr, 1999: 266-98). The political and cultural repercussions of these events reverberate today. Popular histories of transfusion medicine, such as the well-funded documentary Red Gold on US Public Television (Starr et al., 2002), often position the outbreak of HIV within blood supplies as a telos of transfusion medicine, a seemingly inevitable byproduct of technological advance, shaking faith not only in government, but in science itself. And as the Peruvian examples further illustrate, these controversies by no means belong only to a past lurking just beneath the surface of institutional memory.

In the US, the recriminations following the revelation that early steps to reduce disease were not taken (blame was also self-directed by members of the gay community; see Shilts, 1987) may echo today in the resistance of the Food and Drug Administration's (FDA) Blood Products Services Advisory Committee to change its policy guidance. In May 2007, reaffirming a policy statement from 2000, the FDA Blood Products Service Advisory Committee, the standard-setting body for transfusion medicine in the US, opted to continue the 24-year-old policy preventing sexually active gay men from donating blood. The decision followed comprehensive reviews of the 'MSM'-exclusion in $1998^{4}$ and again in $2006 ;{ }^{5}$ the later review spurred in part by efforts of major blood procurement organizations, including the Red Cross and the American Association of Blood Banks, to persuade the FDA to alter its policy. 
The above mentioned scandals involving transfusion-transmitted viral infections (TTVI) notwithstanding, over the course of the 1980s and 1990s, risk of TTVI was in fact progressively lowered through a combination of donor selfinclusion and more precise testing of blood for possible pathogens. Contemporary blood donor activism in the US and other rich countries is closely linked to the advent of nucleic acid testing (NAT) for both HIV and hepatitis C, implemented for blood supplies in the US in 1999. NAT narrows the 'window period' between time of infection and possible detection to as little as 12 days. As a result, residual risk of TTVI involving HIV has been reduced to levels so small as to be unmeasurable.

The risks of HIV and HCV transmission are so low that they cannot be measured: rather they must be estimated by models. Yet, a single transmission can garner media headlines, public sympathy, and public outrage, emphasizing the residual risk rather than the relative safety of transfusion and reinforcing the public's retained belief that the blood supply is not safe. (AuBuchon, 2003: 1377)

Given these facts, many criticized the FDA's decision not to revise its guidance, including even Dr Arthur Caplan, former Chair of the FDA's Advisory Panel on Blood Donation, in a widely circulated editorial:

Letting gay men give blood could help bolster the supply. But, incredibly, despite ongoing shortages of blood that can and do cost lives, and no artificial substitute on the horizon, the FDA is letting prejudice and fear - not science - determine whether gays can give blood. At one time, long ago, the gay-blood ban may have made sense. But it no longer does... The FDA just does not get it. Fear and prejudice are terrible reasons to let you or someone you love die. 6

Most other national guidelines excluding gay male blood donors have also remained in place, despite the advent of NAT, following similar guidance (similar to that of the US FDA) from organizations such as the Council of Europe.

Yet, AuBuchon's final observation above is crucial. The science of TTVI risk is both contested and changing; Busch (2006) provides a recent review. If the risk is so low as to be unmeasurable in countries having implemented NAT screening, the public perception of these facts appears to remain: any risk at all is tantamount to a threat. Yet far from distorting the science of risk, such perceptions instead acutely capture its social meaning. It is beyond the scope of the present article, and beyond the expertise of its author, to assess risk as such. I do, however, wish to problematize here the way in which constructions of risk figure in discussions of blood donation and transfusion medicine. With Beck (e.g. 1994), I note that reflexive awareness of risk, mediated by expert knowledges, is a defining feature of modern technological society. Moreover, with Douglas (1992: 45, 50), I note that what Beck and the experts call 'risk' in earlier times might have been assessed simply as danger. Douglas observes that contemporary 
rhetorics of 'risk' certify the knowledge in play as objective and scientific, while concealing its inherently political dimensions. She argues that languages of risk, like languages of threat everywhere, are always pressed into political claims about the public good. Her argument is never that risks are not real. Rather, her simple and profound point is that all dangers cannot be known. The ones that receive public focus are therefore those that touch a political nerve and that respond to pressing questions about how people wish to live together.

Transfusion would seem to be a case study in the social relativity of risk. The experts themselves are aware of this, as when they bring into discussion the costs associated with diminished risk. Robust surveillance of blood supplies is an expensive endeavor, and the benefits of increased safety (or simply the perception thereof) must be measured against costs incurred, especially in countries, such as Peru, with limited funding for public health (Cruz and Pérez-Rosales, 2003). In the trans/national debates about exclusion of gay male donors, such costs are calculated in terms of potential loss of donor blood, especially in situations of chronic blood shortages (see e.g. Germain et al., 2003). Furthermore, the intense public focus on HIV in relation to blood supplies has clouded from view a number of other dangers that accompany transfusion medicine. AuBuchon continues:

\footnotetext{
Because the transmission of HIV or HCV is an event the public understands and fears, we continue to direct our attention at this risk. In doing so, we are focusing on an event that has a probability of occurring that is diminishing with each blood supply improvement that is implemented. Although such an event can have devastating and tragic consequences should it actually happen, we are simultaneously ignoring risks that are of much greater magnitude that can be medically significant or even deadly. ... The risks of mistransfusion, bacterial contamination of platelets and transfusion-related acute lung injury are well known among transfusion medicine specialists. The number of lives claimed by these events or the impact of reducing their probability can be calculated, providing compelling evidence that a redirection of our efforts would improve transfusion safety. (2004: 1377)
}

Krombach et al. (2002: 154) concur, arguing that 'tranfusion-transmitted HIV infection is approximately 50 to 100 times less likely to occur than transfusion error'. Such errors include the substantial danger that occurs when the wrong blood type is accidentally administered to a patient. Continuing, they write that lack of awareness: 'may have been encouraged by the scarcity of reports on transfusion error relative to the tremendous public attention focused on HIV infection' (2002: 154; see also Regan and Taylor, 2002). Krombach et al. (2002), AuBuchon (2004) and others maintain that a more objective assessment of transfusion risk is an attainable goal, and that outsized attention to HIV risk can ultimately be corrected by better science. Their concern is not with considering the cultural dynamics and consequences of fear or with the politics of purity. Risk assessment in relation to blood supplies, wedded to an aesthetic of numbers, 
rarely reflexively interrogates the political aspects of its normal science paradigm. But while expert risk discourse speaks of numbers and probabilities, individuals who want to donate may find themselves living under a description they would wish to repudiate (cf. Waldby et al., 2004).

In October 2007, 'Samostorm', the YouTube screen name of a high school student in the San Francisco Bay Area, posted a video to the international online video site about his experience earlier in the day at a school blood drive. ${ }^{7}$ In a light blue T-shirt, white iPod headphones draped from ears to shoulders, and longish hair, he broadcast a message to a vast online public with an air of exasperation inflected with occasional emotional angst:

I am kind of upset right now. Today my school was having a blood donation drive and I wanted to donate blood. So I went, and signed the form, and read the little pamphlet and everything like that, and then they took me into this little back room and they had a little questionnaire to fill out, and with questions such as like have you ever done any needle drugs, have you been diagnosed with HIV or syphilis, things like that. And one of the questions was, have you ever had sexual contact with a male since 1977? And I answered yes, and then I filled out the questionnaire, and then I called the nurse over, and then she came and reviewed the answers and then she saw the fact that I had had sexual contact with a male since 1977 and she said, 'I'm sorry but you can't donate blood.' And I said 'Why?' And she said, 'You've had sexual contact with a male.' And I said, 'So what?' And I understand that gay people ... it used to be 'gay cancer,' and all that fucking bullshit. I understand that. But I don't have AIDS. I haven't had sex in a year and a half, and I am not allowed to give blood to help people? I am not allowed to give blood to help save someone's life because I had sex with a man.... [eyes roll] There was no one in that blood drive, and I went there to go give blood, and I am not allowed to give it because I am gay. Or not because I am gay, because [sighing and gesturing in air quotes] 'I have had sexual contact with a male.' I just don't see the point in that. I just don't see, it's retarded to me. It's stupid to me. And perhaps they do it to save money because it would be expensive to test, but it says that every single time blood is donated they have to test it anyways, so what is the point of saying that I can't even donate blood because I have had sexual contact with a male? [eyes roll] ... I don't know. ... It's stupid - it really is stupid. I could have helped someone but now I can't because this world believes that it is still gay cancer.

Some ways in which blood donation institutes kinds of persons become visible. As the video diarist recounts, the scene of donation is one of interpellation and self-examination, indeed the potential donor is required to view himself through the categorical exclusion to which he is subject. Here the abstract discourse of risk touches the bodies of those it purports to describe. If the truth of the modern subject is revealed in its sexuality, in part because sexuality constitutes a link between the disciplining of the individual body and the surveillance of populations, then the scene of donation becomes one theater of that surveillance: a scene of introspection, and reflection, a circumstance in which one is required to enunciate the truth of oneself as a sexual subject. 'Virtue' (altruism, honesty) and 'value' (transfusability, purity) are tightly linked in the reproduction of the vital 
public, a linkage often initially experienced by persons at the donation scene itself. Indeed, in my research on this issue, I have noted that almost all global activism occurring on this issue is the product of young gay men. In North America especially, college campuses and high schools become sites for staging a refusal of this form of interpellation. I turn now to three examples where such refusal motivates public campaigns to remove the exclusion.

\section{Hong Kong: 'They Are Stigmatizing that Gay People Are Dirty, Every Day. If It Is an Education Battle, I Am the One Losing...'}

In May 2001, more than 40 gay activists disrupted a World Red Cross Day ceremony in Kowloon Bay, Hong Kong, an event attended by powerful figures in the Hong Kong medical establishment, including Secretary for Health and Welfare Dr Yeoh Eng-Kiong. The protest, reported worldwide in the gay press, was led by Tommy Chen Noel, a principal organizer of Rainbow of Hong Kong, a gay activist organization. Chen Noel had earlier been provoked by his own personal encounter with donor exclusion: he had been refused as a donor because of his sexual history, even though he felt he presented no risk. He was, he told me, 'pretty upset'. The 2001 'direct action' was the third step in a multi-tiered effort to push for reform. In his subsequent organizing around the issue, Chen Noel sought cross-national linkages for possible models for reform of the Hong Kong Red Cross's policy of excluding MSM from donating blood. First, Chen Noel circulated a letter calling for revision of the guidelines - a letter he says was signed by over 200 AIDS and gay activists in Hong Kong. Next, he reviewed litigation in places like Australia and the Netherlands.

At the beginning of my activism, I did research on the world, seeing if there was some case or situation that I can compare, such that when the press asks me, then I can say, you can have reference to other guidelines in the world that are better. But the blood donation guidelines around the world, none of them I was happy with. Most of them at the time were using the word 'gay', but later on, because a lot of gay activists were preaching about it, a lot of them changed to 'men who have sex with men', and a lot of them had time constraints, like if you had had sex in the last ten years or something like that. But none of them I was happy with, including America, Europe, Canada, Australia...

Following a court case in the Netherlands, Chen Noel approached Hong Kong's Equal Opportunity Commission, a human rights body (not a court of law). Knowing that Hong Kong did not protect sexual orientation as a category for discrimination, Chen Noel argued that the ban on gay men donating blood amounted to discrimination on the basis of gender. He lost his case, noting a transnational irony in the rationale of this decision. As he recounted to me: 
You know the term 'men who have sex with men' was created through AIDS outreach, in the AIDS world? They found it especially efficient in the Middle East because those men do not identify themselves as gay, they are straight. But they have a lot of sexual activities with other men. So this has something to do with blood discrimination guidelines. In the Netherlands, there is a law, an anti-discrimination law prohibiting discrimination on the basis of sexual orientation. But the gay activists lost their case [arguing that blood guidelines were discriminatory], because it was not about 'sexual orientation' it was about 'sex', since the guidelines did n.ot mention 'gay' but instead 'men who have sex with men'.

In Hong Kong there is no prohibition on sexual orientation discrimination, so I brought a case saying they are sex discriminating. If I am a woman who has sex with a man, then I am allowed to donate blood. If I am a man who has sex with a man, then I am not allowed to donate blood. So that is sex discrimination. But the anti-discrimination commission did their research and answered that this is 'sexual orientation' discrimination and was not prohibited. (video conducted online: Helsinki - Hong Kong, March 2008)

Frustrated by the refusal of the Red Cross to respond to his initial letter not to a subsequent book he compiled detailing complaints about the ban on gay donors (Chen Noel says that as many as 2000 copies were printed), Chen Noel then planned the May 2001 direct action.

We were carefully organized. And there were big political celebrities there. And they were not expecting us to show up. And there were lots of press, including TV cameras. We were a well organized protest. I even had friends upstairs holding banners. Sending leaflets to the people there. And then we very strategically planned it. So they were on the balcony yelling, and everyone was looking up. And I had two of my friends, who are much bigger and stronger, downstairs they helped me break through the security. So I personally got into the middle of everything, standing in front of the two big celebrities that everyone knows, and hand them the book. And they are like very good, angel-faced celebrities. They are good people. Their political image was always very positive, until that event. Because the news headlines, including the TV news, said they were sneaking away through the backdoor, that they did not respond to our protest. A couple of newspapers were talking about how they were sneaking away. That they did not respond to our protest and avoided responding to questions from the media. So they were very angry and we got in trouble after with the security. But after that, I was worried because they were very powerful people. So after that, we didn't get any more funding. We kept writing proposals but we just didn't get any. We lost our center after that. I don't have proof that's what they did to us, but we lost our organization.

Following in part the lead of activists he had read about online, Chen Noel emphasized the issue of 'discrimination' in his public rhetoric. However, when I asked him if he thought gays, or all people, have a 'right' to give blood, he said no. He also suggested that if gays wish to give blood they could easily simply decline to defer themselves - that is, they could deceive phlebotomists and donate anyway. Chen said that in fact his principal concern was educating the public and impacting public perceptions of gay men.

The Red Cross is a big authority organization, well actually there were two. One was the Red Cross, the other were hospitals. So the Red Cross only gathered the blood, or draw the blood 
from your body. Every other procedure was in the hospital section, and they did all the tests and stuff. And the blood donation guidelines have both organizations' symbols on them. And they are well recognized symbols, right? So I said, they are very authoritative. And they had a very medical and scientific image, but they are teaching people that if you are gay, or if you have sex for money, then your blood is dirty. And I said, that's what bugs me. It is not about whether I can donate blood or not. What I would say in lectures [at colleges] is that they teach how many people? More than a thousand people, every day - I got the statistics, in Hong Kong about 1000 people donate blood every day - so about 1000 people read those guidelines, every day. So I said that education is far bigger than whatever education I am doing (about gay people). So I am losing the battle. In classes where I would talk, I would say I am talking to 30 of you, but they are talking to 1000 people every day. And they are stigmatizing that gay people are dirty, every day. If it is an education battle, I am the one losing.

This story well illustrates how contemporary categories of person ('gay', 'MSM') emerge at the interstices of biomedical discourse, global social movements and everyday experience. Moreover, Chen Noel's activist response to this coincident intersection of role and risk responds to and refigures a 'vital public' as it attempts to resignify the categories of person who may participate in it.

\section{The United States: 'When I First Started Making These Blood Drives, I Didn't Qualify as a Banned Person, Yet. But of course, Eventually You Grow Up...'}

Across the United States, college campuses are grappling with the guidelines set forth by the US federal government excluding gay men from donating blood. While schools have long been a significant supplier of donors to blood organizations, in the US many campuses have enacted non-discrimination policies protecting gays and lesbians. For some school administrators, the conflict between federal guidelines and local policies has created a conundrum. In 2008, the San Francisco Bay Area was ground zero for these conflicts. In January of that year, the president of San José State University, Don W. Kassing, issued an executive order suspending on-campus blood drives because they conflict with the university's official non-discrimination policy. Kassing's public letter noted much of what I have described here - the development of more precise testing technologies, the support of major blood organizations for inclusion of gay male donors, and so on - while sharply criticizing the FDA guidelines, suggesting that the guidelines are rooted in bias against gay men rather than current science. The decision garnered both support and criticism in subsequent (and ongoing) discussion. Many critics pointed out the irony that, in diminishing the pool of potential donors by removing an especially effective venue for recruitment, Kassing's decision could be argued to threaten lives. Supporters countered that the dramatic nature of the decision might help catalyze reform, and therefore ultimately contribute to a larger donor pool that includes gay men. Other campuses in the 
area followed suit, the Santa Clara County Board of Supervisors passed a resolution condemning FDA policy, and US representatives from the area also took notice. On 2 April 2008, a US Representative Sam Farr from San José debated with FDA officials at a public appropriations hearing in Washington, DC, joining with other area representatives in calling for further review of the policy.

The decision was reported in campus newspapers across the country - dozens of campus protests have occurred over many years - including at Boston University, Indiana University, Stanford University, the University of Wisconsin. At the University of California, Berkeley, 60 miles north of San José State University, student activists attempted to draw attention to the issue by innovating a new type of blood donation - the 'sponsored donation'. First organized in 2007, and repeated again in 2008, the sponsored drive was created cooperatively with the campus Red Cross and the campus lesbian and gay organization. In the sponsored drive, students restricted from donating under the ban recruit others to donate 'in their name', enabling a form of participation that calls attention to their exclusion by substituting the blood of another. ${ }^{8}$ The Berkeley campus drive evoked the discourse of rights in inventing a new kind of blood donation: all people, campus flyers suggested, have 'the right to give life' (Manassero, 2008; see also Figure 1), illustrating ways in which participation in the vital public is often rhetorically conceived as a privilege and duty of citizenship.

Across the country, at a small college in New England, activists explicitly drew on the Berkeley example to stage their own sponsored blood drive. Aware that prior activism in New England had created tense conflicts between campus activists and the Red Cross, activists at Middlebury College themed their intervention in the conciliatory terms of dialogue and enlightenment. The principal organizer of the Middlebury action was Ryan Tauriainen, President of the Middlebury Open Queer Alliance (MOQA). Tauriainen created what he calls 'The Middlebury Model: An Educated Approach to Protesting Blood Drives', a document he distributes to other campus activists with advice and materials.

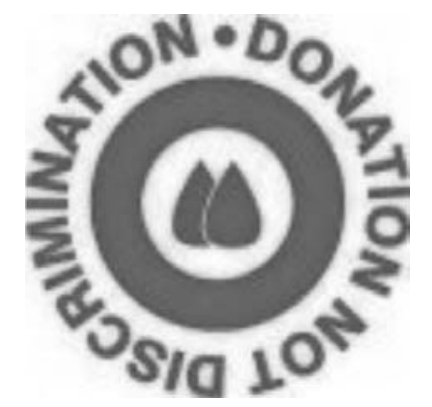

Figure 1 Linking 'the right to give life' to anti-discrimination discourse 
Tauriainen, with the assistance of the local chapter of the Red Cross, organized an 'open forum' to educate the campus and the public at large about the FDA policy and alternatives, drawing hundreds of students, faculty, and staff into public dialogue.

Like Chen Noel, Tauriainen drew on transnational developments to make a case for national reform - he noted changing standards in different national settings (see above) when I spoke with him. And like Chen Noel, Tauriainen's experience of donation, and his passionate response to exclusion, exposes the tight linkages between self-awareness - and especially sexual experience - and the biopolitical body, or the vital public, elicited through donation discourse and practice.

When I was in high school, I did service projects in high school. I ended up coordinating six blood drives while I was in high school, and they were some of the most successful blood drives that they had in our area, certainly in the Grants Pass area, through that I became interested in this. I worked closely with the Red Cross, I knew from the start that they had these bans. When I first started making these blood drives, I didn't qualify as a banned person, yet. But of course, eventually you grow up and suddenly I no longer can give blood according to the ban.... The act of giving blood was really close to - it was something I really enjoyed doing ... it was very important to me. For that to suddenly be taken away for reasons that I thought were absolutely ridiculous ... I took it very personally. (Voice interview conducted online: Helsinki - Middlebury, VT, March 2008)

Facing what he feels is a bureaucratic absurdity, Tauriainen petitions, corresponds, and pounds the pavement. His work is enlivened by a sense of anger, and again, of refusal. One of the posters he created to help mobilize attention reads 'The FDA $=$ Fags Donate AIDS. Help motivate the FDA to change its view on gay men' (Figure 2). Continuing a long history of confrontation between gay men and the FDA (Tauriainen is familiar with the ACT UP activism of Larry Kramer), Tauriainen says that the current restrictions are simply a further example of entrenched anti-gay bias in the halls of government.

The message I am trying to get across is that they can no longer say this is about protecting people from HIV, when all these studies and all the scientific evidence is showing that because of the testing that they have available, and because of the other, what they consider to be high risk behaviors, the way that they treat those, this is less about an AIDS scare and more about homophobia. The fact that a man can have unprotected sex with hundreds, literally hundreds, of prostitutes - illegally - and as long as it has been a year, one year since he is engaged with a prostitute, like that, there is such a disconnect between that logic and literally, let's say a man receives oral sex from another man, and let's say he's wearing a condom during this oral sex, and he only did it once in his life, and they were both virgins or something (amused), that situation where it is impossible to get AIDS, that is a lifetime ban. The thing is, situations where it is impossible to get HIV result in a lifetime ban and situations where it is entirely possible to get HIV, because you are having sex with a prostitute, is a one-year ban. This disconnect is absolutely ridiculous. And the fact that other versions of the Red Cross, in other countries, have recently lifted the ban, it just goes to show that there is more there than just a fear of AIDS. There is a completely other fear there, and I think it's just homophobia. 


\section{The FD $A=$ \\ Fags Donate AIDS}

\section{Help motivate the FDA to change its view on gay men.}

Figure 2 Talking back to bureaucratic indifference

\section{The UK: 'Unless Tea and Biscuits Are Legal Tender in Scotland ...'}

Examples accumulate right across the globe. On 15 April 2008, Rob McDowall and Nick Henderson, petitioners before the Scottish Parliament, called for reform of the National Blood Service of the United Kingdom. Early in his testimony, McDowall noted: 'Australia, Spain, South Africa, Russia, Italy, and Thailand allow men who identify themselves as being gay or bisexual to give blood. ${ }^{\prime} \mathrm{He}$ continued:

I ask the committee to consider the position that I was in, when I was 19 years old, as I queued up to give blood. I was full of excitement and wanted to make a difference - to give the gift of life. However, I was told that, unfortunately, I could not give blood due to my lifestyle choices.... Giving blood in the UK is not met with a payment, unlike the situation in other countries. Money does not change hands - unless tea and biscuits are legal tender in Scotland. It is a selfless act, and it is one of the only things left in the world that is done for the good of mankind.... Our society is one that celebrates diversity and equality. Being gay is recognized as a fundamental part of the human condition. The petition is not about blood amnesty, and it is not demanding that the doors should be opened tomorrow to everyone who wants to give blood. There are certain people who should not give blood due to their individual behaviour, such as participating in unprotected sex. It is not about pushing a statute to introduce the right for everyone to give blood... Specific behaviour, such as having unprotected sex, would exclude someone from giving blood. That should be the case for gay and heterosexual males who present themselves at the transfusion service.

McDowall noted that the UK National Blood Service argues that pervasive sexual questioning would deter potential donors. He further noted, however, that gay men are already subject to such questioning. In a sense, both petitioners sought to expand the rhetorical range of 'risk', bringing heterosexual practices into the full embrace of the biopolitical surveillance enacted at the scene of donation. If many gay men seek to remove the stigma of AIDS from gay identity through 
blood donor activism, a complementary strategy might therefore also be to emphasize HIV risk for all. Either way, a liberal social imaginary of equality and choice intersects with the vital publics that contribute to and comprise social life the world over. Here, as in the examples from the US and Hong Kong, participation in the vital public mixes claims about rights and risks with rhetorics of altruism and obligation.

Contestation over donor exclusions therefore displays contemporary dynamics of biological citizenship while also revealing complexities in the sociality and symbolism through which vital publics take shape.

\section{Sex and Blood: Conclusion}

In a famous passage from his History of Sexuality, Foucault writes (1990: 147-8):

The blood relation remained an important element in the mechanisms of power, its manifestations, and its rituals. For a society in which the systems of alliance, the political form of the sovereign, the differentiation into order and castes, and the value of descent lines were predominant; for a society in which famine, epidemics, and violence made death imminent, blood constituted one of the fundamental values. It owed its high value at the same time to its instrumental role (the ability to shed blood), to the way it functioned in the order of signs (to have a certain blood, to be of the same blood, to be prepared to risk one's blood), and also to its precariousness (easily spilled, subject to drying up, too readily mixed, capable of being quickly corrupted). A society of blood - I was tempted to say, of 'sanguinity' - where power spoke through blood: the honor of war, the fear of famine, the triumph of death, the sovereign with his sword, executioners, and tortures; blood was a reality with a symbolic function. We, on the other hand, are in the society of 'sex,' or rather a society 'with a sexuality': the mechanisms of power are addressed to the body, to life, to what causes it to proliferate, to what reinforces the species, its stamina, its ability to dominate ... our societies go from a symbolics of blood to an analytics of sexuality. Clearly, nothing was more on the side of the law, death, transgression, the symbolic, and sovereignty than blood; just as sexuality was on the side of the norm, knowledge, life, meaning, the disciplines, and regulations.

Well, not so fast. As much scholarship in critical dialogue with Foucault's story has shown, this putative superseding of the symbolics of blood by the analytics of sexuality problematically occludes transformations in symbolics and logics of 'blood' in connection with modern political projects of European nations, including their colonial projects. Especially salient here are studies showing that 'blood' quanta were central to the imagination of the biopolitical body as a racial body (e.g. Stoller, 1995), a logic interdigitating blood and sex as indexes of forms of political power. But more to the point, today it appears manifestly true that blood has become ever more central to the symbolic and the somatic reproduction of society. In this passage, blood ethnologically or ethnographically (Biddick, 2000: 452) typifies an earlier social and political imaginary or iconicity, 
a structural mode of linking the bodies of persons and polities through the reign of sovereign power. Has blood receded from view as a key symbol of and means through which contemporary socialities emerge? And are blood and sex quite opposed as constituting topoi of contemporary social imaginaries? On the contrary, in many settings, people today learn the social meaning of their sexuality through connection to their blood. As my cumulative examples illustrate, this fact appears more - not less - true, including circumstances where gay men are not prevented from donating blood, but are nevertheless required to examine themselves as sexual subjects in order to do so. If, like many before us, we might wish to revise Foucault's periodization of an epoch sanguinis, we might nonetheless do so by saying that blood today is one medium for the normalization of persons through the instrument of the vital public to which they belong.

The question of the time of transfusion persists (cf. Copeman, 2005). Foucault casts a dark and doubting eye on a shift that many others have celebrated. From ascription to contract, from inheritance to self-determination, from community to association, and so on: markets, science and democracy (among other familiar keywords) untether the restrictions of traditional social orders, liberating the individual. The edifying moral narrative of modernity often allegorizes the release of the individual from the bonds of community in the imagery of blood. In the context of blood, and its social circulation, twin vectors capture the analytic imagination - a movement from the 'genealogical' person to the 'autologous' self (see Povinelli, 2006: 4 and passim), ${ }^{10}$ and the movement from 'gift' to 'commodity'. But it is something of a surprise, then, to witness, along with the young men described in this article, the tightening of the bonds of community through symbols and substances once consigned to a superseded past. As freedoms, including sexual liberties, accumulate, people find themselves seemingly paradoxically more intimately bound to others, and their intimate acts, than ever.

Contemporary developments in medicine, technology, biology, law, the market and so on - and especially contemporary developments that draw together these domains of inquiry and practice - disabuse us of our enchantment with the new, even as we describe and analyze unprecedented means and media for creating relationships. At the very moment when human nature appears to be rewritten by technological enterprise, old questions and constructs spring forward. Biotechnological time mixes frames and registers, and the now appears simultaneously 'then': as when advances in technology presage not the disappearance of 'human dignity' but rather its continuing problematization, when human nature is evoked even at the moment when it appears most subject to transformation, and, in the present example, when consanguineal bonds continue to define people and their relations even as the family appears to be under threat from all sides. Is 
it any wonder that, remembering Douglas, we note that languages of risk reproduce logics of sin, and it is precisely these that offend the gay activists who today refuse them?

Both whole blood and its industrial derivatives have become central to modern healthcare systems, and as the health and well-being of populations comprises an important and perhaps primary principle of politics, it might be said that the circulation of blood is not a metaphorical symbol of nation, but rather comprises a 'political economy of life', a mode of producing the nation through the blood it shares. If this is true, attending to the meaning and manner of procurement of blood in contemporary societies is no small topic, no specialty within medical anthropology, and the resistance to exclusion I have tracked is not only the concern of a small minority. I instead suggest that the relational form of a 'vital public' is reflexively made visible in these contestations, and that the questions and quandaries thereby revealed go right to the heart of the meaning of modern human being.

\section{Acknowledgements}

Research and writing were supported by a post-doctoral fellowship at the Centre of Excellence in Global Governance Research at the University of Helsinki. I wish to thank Jacob Copeman, Robert E. Moore, Lisa Wynn, Susanna Trnka, Barbara Prainsack and Courtney Handman for helpful commentary. A draft of this article was read in a seminar in the department of anthropology at the National University of Ireland, Maynooth, where my colleagues provided cogent criticisms. Any errors remain my own.

\section{Notes}

1. See Tasmanian Gay \& Lesbian Rights Group (2005). News reports on the Cain hearing circulated globally throughout 2008. A decision by the tribunal was pending as this article went to press.

2. Compare notions of the 'biological commons' in Reddy (2007) and Waldby and Mitchell (2006). My usage of 'public' here refers to modes of (stranger) relationality created through a specific mode of circulation: the altruistic donation. I seek to innovate upon already influential interrogations of 'gift' and 'commodity' in the context of blood supplies.

3. This article is based on research conducted in 2007-8, updating ethnographic fieldwork conducted in 1993-6 in the United States on the subject of blood donation; I conducted in-depth interviews with activists from the UK (both Scotland and England), from several locations within the United States, and from Hong Kong. The article reports on important changes occurring in sensibilities about blood donation. Many of these phenomena continue to develop, and my ongoing research is tracking these developments.

4. Department of Health and Human Services, Food and Drug Administration, 'Blood Donor Suitability Workshop', 23 November 1998, transcript available at URL (consulted May 2008): http:// www.fda.gov/cber/minutes/bld112398trans.pdf

5. Department of Health and Human Services, Food and Drug Administration, 'FDA Workshop on Behavior-based Donor Deferrals in the NAT Era', 8 March 2006, transcript available at URL (consulted May 2008): http://www.fda.gov/CbER/minutes/nat030806t.htm 
6. 'Old Fears Draining the US Blood Supply', 23 May 2007, URL (consulted May 2008): http:// www.msnbc.msn.com/id/18832082/. This editorial was syndicated nationally and is widely cited.

7. As with nearly any political issue today, much of this debate takes place online. There are many videos on YouTube addressing the issue from all sides; college bulletin boards host debates; individuals blog their opinions; news articles host threads of discussion.

8. This very recent development merits further research. I am presently working with activists at several locations in the US on this topic.

9. Transcripts of this testimony available at URL (consulted May 2008): http://www.scottish. parliament.uk/s3/committees/petitions/or-08/pu08-0601.htm; I have also corresponded with Henderson and McDowall.

10. I here draw on Povinelli's contrast between 'genealogical society' and the 'autological subject', where the 'autological subject' is the social actor as imagined in liberal discourses of individual freedom, and 'genealogical society' refers to constraints placed on subjects by virtue of inheritances of various kinds, including the body. Note that autologous transfusion is one contemporary method by which persons seek to mitigate the risks associated with transfusion.

\section{References}

Agence France-Presse (2008) 'Thai Red Cross Ends Separate Screening for Gay Blood Donors', 10 April, URL (consulted May 2008): http://afp.google.com/article/ALeqM5iryUiYCXAyEoTYcqEvVtMJAcCwHQ

Arnoldi, J. (2006) 'Autopoiesis'. Theory, Culture, and Society 23(2-3): 116-117.

AuBuchon, J.P. (2004) 'Managing Change to Improve Transfusion Safety', Transfusion 44: 1377-83.

Bayer, R. (1999) 'Blood and AIDS in America: Science, Politics, and the Making of an Iatrogenic Catastrophe', pp. 19-58 in E.A. Feldman and R. Bayer (eds) Blood Fends: AIDS, Blood, and the Politics of Medical Disaster. Oxford: Oxford University Press.

BBC News (2007) 'Peru Blood Banks Face HIV Crisis', 14 September, URL (consulted May 2008): http://news.bbc.co.uk/1/hi/world/americas/6994291.stm

Beck, U. (1994) 'The Reinvention of Politics: Towards a Theory of Reflexive Modernization', pp. 1-55 in U. Beck, A. Giddens and S. Lash (eds) Reflexive Modernization: Politics, Tradition, and Aesthetics in the Modern Social Order. Stanford, CA: Stanford University Press.

Biddick, K. (2000) 'The Cut of Genealogy: Pedagogy in the Blood', Journal of Medieval and Early Modern Studies 30(3): 449-62.

Biehl, J. (2007) Will to Live: AIDS Therapies and the Politics of Survival. Princeton, NJ: Princeton University Press.

Boellstorff, T. (2005) The Gay Archipelago: Sexuality and Nation in Indonesia. Princeton, NJ: Princeton University Press.

Busch, M.P. (2001) 'Closing the Windows on Viral Transmission by Blood Transfusion', pp. 33-54 in S.L. Stramer (ed.) Blood Safety in the New Millennium. Bethesda, MD: American Association of Blood Banks.

Busch, M.P. (2006) 'Transfusion-transmitted Viral Infections: Building Bridges to Transfusion Medicine to Reduce Risks and Understand Epidemiology and Pathogenesis', Transfusion 46: 1624-40.

Churchill, W.H. and S.P. Kurtz (eds) (1988) Transfusion Medicine. Boston, MA: Blackwell Scientific.

Collier, S., A. Lakoff and P. Rabinow (2004) 'Biosecurity: Toward an Anthropology of the Contemporary', Anthropology Today 20(5): 3-7.

Comaroff, J. (2007) 'Beyond Bare Life: AIDS, (Bio)Politics, and the Neoliberal Order', Public Culture 19(1): 197-219.

Copeman, J. (2005) 'Veinglory: Exploring Processes of Blood Transfer Between Persons', Journal of the Royal Anthropological Institute 11: 465-85. 
Copeman, J. (2008) 'Violence, Non-violence, and Blood Donation in India', Journal of the Royal Anthropological Institute 14: 277-95.

Crimp, D. (ed.) (1988) AIDS: Cultural Analysis/Cultural Activism. Cambridge, MA: MIT Press.

Cruz, J.R. and M.D. Pérez-Rosales (2003) 'Availability, Safety, and Quality of Blood for Transfusion in the Americas', Pan American Journal of Public Health 13 (2/3): 103-10.

Cullinane, J. (2005) 'Tainted Blood and Vengeful Spirits: The Legacy of Japan's Yakugai Eizu (AIDS) Trial', Culture, Medicine and Psychiatry 29: 5-31.

Dalsgaard, S. (2007) “I Do It for the Chocolate”: An Anthropological Study of Blood Donation in Denmark', Distinktion 14: 101-17.

Douglas, M. (1992) Risk and Blame: Essays in Cultural Theory. London: Routledge.

Erwin, K. (2006) 'The Circulatory System: Blood Procurement, AIDS, and the Social Body in China', Medical Anthropology Quarterly 20(2): 139-59.

Feldman, E.A. and R. Bayer (eds) (1999) Blood Feuds: AIDS, Blood, and the Politics of Medical Disaster. Oxford: Oxford University Press.

Foucault, M. (1990) The History of Sexuality, vol. 1. New York: Vintage.

Fox, R. and J. Swazey (1974) The Courage to Fail: A Social View of Organ Transplants and Dialysis. Chicago, IL: University of Chicago Press.

Fraser, B. (2005) 'Seeking a Safer Blood Supply', The Lancet 365: 559-60.

Germain, M., R.S. Remis and G. Delage (2003) 'The Risks and Benefits of Accepting Men Who Have Had Sex with Men as Blood Donors', Transfusion 43: 25-33.

Hacking, I. (2006a) 'Genetics, Biosocial Groups, and the Future of Identity', Daedalus 135(4): 72-80.

Hacking, I. (2006b) 'Making Up People', London Review of Books 28(16).

Healy, K. (2000) 'Embedded altruism: Blood collection regimes and the European Union's donor population'. American Journal of Sociology 105: 1633-57.

Herzfeld, M. (1992) The Social Production of Indifference: Exploring the Symbolic Roots of Western Bureaucracy. Chicago, IL: University of Chicago Press.

Herzfeld, M. (2004) Cultural Intimacy: Social Poetics in the Nation-state. London: Routledge.

Hochberg, F.A. (2001) 'HIV/AIDS and Blood Donation Policies: A Comparative Study of Public Health Policies and Individual Rights Norms', Duke Journal of Comparative E International Law 12: $231-80$.

Kramer, L. (1989) Reports from the Holocaust: The Story of an AIDS Activist. New York: St Martin's Press.

Krombach, J., S. Kampe, B.S. Gathof, C. Diefenbach and S.-M. Kasper (2002) 'Human Error: The Persisting Risk of Blood Transfusion', Anesthesia E Analgesia 94: 154-6.

Lakoff, A. (2007) 'Preparing for the Next Emergency', Public Culture 19: 247-71.

Manassero, J. (2008) 'Still Fighting for the Right to Give Life: Sponsor Drive Allows Those Who Can't Donate to Save Lives While Still Making a Statement', Daily Californian 4 April, URL (consulted May 2008): http://www.dailycal.org/article/101146/still_fighting_for_the_right_to_give_life

Masco, J. (2006) The Nuclear Borderlands: The Manbattan Project in Post-Cold War New Mexico. Princeton, NJ: Princeton University Press.

Parsons, T., R.C. Fox and V.M. Lidz (1972) 'The "Gift of Life” and its Reciprocation', Social Research 39: 367-415.

Patton, C. (1990) Inventing AIDS. New York: Routledge.

Petryna, A. (2002) Life Exposed: Biological Citizens after Chernobyl. Princeton, NJ: Princeton University Press.

Povinelli, E.A. (2006) The Empire of Love: Toward a Theory of Intimacy, Genealogy, and Carnality. Durham, NC: Duke University Press.

Rabinow, P. (1992) 'Artificiality and Enlightenment: From Sociobiology to Biosociality', pp. 234-52 in J. Crary and S. Kwinter (eds) Incorporations. New York: Zone Books.

Rabinow, P. (1999) French DNA: Trouble in Purgatory. Chicago, IL: University of Chicago Press. 
Reddy, D.S. (2007) 'Good Gifts for the Common Good: Blood and Bioethics in the Market of Genetic Research', Cultural Anthropology 22(3): 429-72.

Regan, F. and C. Taylor (2002) 'Recent Developments: Blood Transfusion Medicine', British Medical Journal 325: 143-7.

Rose, N. (2006) The Politics of Life Itself: Biomedicine, Power, and Subjectivity in the Twenty-first Century. Princeton, NJ: Princeton University Press.

Royse, D. and K. Doochin (1995) 'Multi-gallon Blood Donors: Who Are They?', Transfusion 35: 826-31.

Scheper-Hughes, N. (1993) 'AIDS and Human Rights in Cuba', Lancet 342: 965-7.

Shao, Jing (2006) 'Fluid Labor and Blood Money: The Economy of HIV/AIDS in Rural Central China', Cultural Antbropology 21(4): 535-69.

Shilts, R. (1987) And the Band Played on: Politics, People, and the AIDS Epidemic. New York: St Martin's Press.

Starr, D. (1999) Blood: An Epic History of Medicine and Commerce. New York: Quill.

Starr, D., J. Dillon and D. Reisman (2002) 'Red Gold: The Epic Story of Blood', (Program Guide) produced by WNET New York, URL: www.thirteen.org

Stoler, A.L. (1995) Race and the education of desire: Foucault's History of Sexuality and the colonial order of thing. Durham NC: Duke UP.

Strathern, M. (1992) Reproducing the Future: Anthropology, Kinship, and the New Reproductive Technologies. London: Routledge.

Strong, T. (1997) 'Blood/Money', Critical Matrix 6: 20-37.

Strong, T. (2002) 'Kinship between Judith Butler and Anthropology?’, Ethnos 67(3): 401-18.

Sullivan, A. (1996) Virtually Normal: An Argument about Homosexuality. New York: Vintage.

Tasmanian Gay \& Lesbian Rights Group (2005) 'Background Information on the Gay Blood Ban', media release 2 August, URL (consulted May 2008): http://tglrg.org/more/127_0_1_30_M2/

Titmuss, R. (1971) The Gift Relationship: From Human Blood to Social Policy, 1st edn. New York: Pantheon.

Titmuss, R. (1997) The Gift Relationship: From Human Blood to Social Policy, 2nd edn. New York: New Press.

Treichler, P. (1988) 'AIDS, Homophobia, and Biomedical Discourse', pp. 31-70 in D. Crimp (ed.) AIDS: Cultural Analysis, Cultural Activism. Cambridge, MA: MIT Press.

Tsing, A. (2000) 'The Global Situation', Cultural Anthropology 15(3): 327-60.

Tsing, A. (2007) 'Indigenous Voice', pp. 33-67 in M. de la Cadena and O. Starn (eds) Indigenous Experience Today. Oxford: Berg.

Valentine, K. (2005) 'Citizenship, Identity, and Blood Donation', Body E Society 11(2): 113-28.

Waldby, C. and R. Mitchell (2006) Tissue Economies: Blood, Organs, and Cell Lines in Late Capitalism. Durham, NC: Duke University Press.

Waldby, C., M. Rosengarten, C. Treloar and S. Fraser (2004) 'Blood and Bioidentity: Ideas about Self, Boundaries and Risk among Blood Donors and People Living with Hepatitis C', Social Science E Medicine 59: 1461-71.

Warner, M. (1999) The Trouble with Normal: Sex, Politics, and the Ethics of Queer Life. Cambridge, MA: Harvard University Press.

Warner, M. (2005) Publics and Counterpublics. New York: Zone Books.

Young, R.M. and I.H. Meyer (2005) 'The Trouble with "MSM" and "WSW": Erasure of the Sexualminority Person in Public Health Discourse', American Journal of Public Health 95(7): 1144-9.

Thomas Strong lectures in the Department of Anthropology at the National University of Ireland Maynooth. [email: thomas.strong@nuim.ie] 